\title{
MITO Y POESIA EN ENRIQUE MOLINA
}

\author{
POR \\ ENRIQUE PEZZONI \\ Buenos Aires
}

TRANSGREsión. Y DESLINDE

«Mientras corren los grandes días», el poema que en "Reino Solitario» (1936-1938) inicia la obra de Enrique Molina ${ }^{1}$, es en más de un sentido un texto programático: da comienzo a una estrategia verbal que irá desarrollándose al modo de un relato con «acontecimientos» bien definidos, sin que la ausencia de un «desenlace» destruya la ilusión de avance y traspaso, de movimiento desde un suceso hacia otro, aun en la circularidad de su reiteración. No empleo el término «acontecimiento» con intención vagamente metafórica al referirme a una poesía que, por su parte, se señala a sí misma - metafóricamente- como narración ( Podríamos comenzar así esta novela incesante», $C E$, p. 100 ; «iOh relato de espumas!», $C E$, p. 21) de situaciones que surgen como realmente vividas (partidas, regresos, encuentros amorosos fugaces e intensos). Un narrar siempre acuciado por el afán de testimoniar la busca de una «verdad» individual, secreta y huidiza («El inconfesable, el transitorio, / el culpable de cada día... ¿Qué es lo que ha sido, sino ausencias?», US, p. 19), ansioso de una precisión («Ahora pido evidencias, certidumbres», US, p. 128) que sólo puede saciarse con el aluvión de imágenes verbales o el símbolo mismo de las correspondencias ocultas ( «... Tantas veces / vuelvo a oír el crujido de la vieja escalera / y la rata que esca-

${ }^{1}$ Cito por la Obra poética (Caracas: Monte Avila Editores, 1978), y para los poemas posteriores a esa edición, por Los últimos soles (Buenos Aires: Editorial Sudamericana, 1980). Siglas: US, Los últimos soles; para los textos reunidos en la Obra completa: CD, Las cosas y el delirio, 1941; PT, Pasiones terrestres, 1964; CE, Costumbres errantes o la redondez de la Tierra, 1951; AA, Amantes antipodas, 1951; FL, Fuego libre, 1962. 
pa. / Y la verdad que sostiene estas cosas / es la araña que teje entre las piedras / la noche que se irisa en un vaso de vino», US, pp. 68-69; "Acaso la luz son sus labios, / ¿y su torso, entre los juncos, al borde del río donde vibró la flauta, / a qué corresponde en la mesa tendida?», $U S$, p. 52). No hay, por cierto, en la poesía de Enrique Molina un pacto autobiográfico con marcas textuales que le otorguen legalidad «jurídica» ante el lector. Legalidad que, por lo demás, sería no pertinente en la poesía lírica; por su esencia, la lírica es (auto)biografía: mimetización de una subjetividad que se perfila como tal no a partir de referentes presuntamente reales, sino de su propio discurso. «Si se tiene en cuenta que el texto lírico no se puede identificar con el discurso del poeta que lo imagina y lo fija verbalmente, sino con el discurso de la fuente instaurada por él para articular por su intermedio vivencias poéticas propias y/o ajenas, es lícito definirlo como resultado de una mimetización que tiene por objeto el posible discurso de un posible carácter que puede estar más o menos próximo al poeta» (Susana Reisz de Rivarola) ${ }^{2}$. Por otro lado, la insistencia en registrar situaciones como inmediatamente vividas o evocadas en lugares concretos y existentes invita a sostener la ilusión de ese pacto ${ }^{3}$.

Con una sola excepción, nunca aparece en los textos de Enrique Molina su nombre: el del autor real que habría protagonizado las situaciones poetizadas. Sí aparecen, una y otra vez, los topónimos de los sitios reales. Desplazamiento de la autonominación: el topónimo es deíctico en el mismo sentido en que lo son «yo» y «aquí». "Ser» y «estar» se equiparan. El punto de referencia del topónimo no es el mundo ni el atlas, sino la subjetividad instantáneamente localizada en la instancia

${ }^{2}$ "La posición de la lírica en la teoría de los géneros literarios» (Lexis, V, 1, 1981, p. 81). La conclusión de la autora surge a propósito de la distinción platónica entre diéguesis simple (acciones del personaje referidas por el poeta), diéguesis a través de la mímesis (acciones - verbales o no- transmitidas sin mediación del poeta) y diéguesis mixta (relato de acciones alternado con acciones verbales de los personajes: «discursos directos»), así como de la distinción aristotélica entre mímesis y poiesis. De acuerdo con una lectura acertada de Aristóteles, la lírica no «es mímesis de acciones, y en segundo lugar de los caracteres que ejecutan esas acciones, sino, a la inversa, ... mimesis de caracteres que se manifiestan a través de acciones verbales» (p. 81).

${ }^{3}$ Cf. las observaciones de Philippe Lejeune sobre ciertas formas de ficción (Gide, Mauriac) que «señalan el espacio autobiográfico en que los autores desean que se lea el conjunto de su obra»: de ese modo incitan "a que se lean las novelas no sólo como ficciones que remitan a una verdad de la "naturaleza humana", sino también como fantasmas reveladores de un individuo. Daré a esta forma indirecta del pacto autobiográfico el nombre de pacto fantasmático». "Le pacte autobiographique» (Poétique, 14, 1973, p. 159). 
del discurso. El texto lo dice: "Yo he sido para siempre, tierra mía, / entre tus arenales» (PT, p. 76). La identificación entre ser y estar se da respecto de lo otro y del otro: «Estuve ante los límites infranqueables de la mujer», dice el «yo» en el poema «Una experiencia» (US, pp. 42-45). En este texto es revelador el paralelismo de las enumeraciones (autodesignaciones) que empiezan con las fórmulas cuasi rituales "he estado" $\mathrm{y}$ «he sido»:

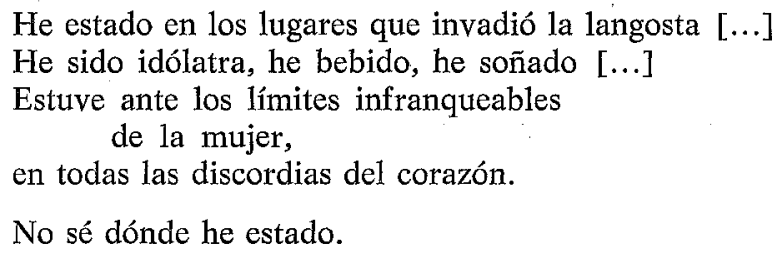

Si el poema se cierra con ese último verso es porque la negación de saber es aparente: lo que se declara es la certeza de la propia subjetividad como ubicuidad. La única ocasión en que aparece el nombre propio «Enrique Molina» se da en el largo poema «Una estancia entre los arenales (Bella Vista, Corrientes)», PT, pp. 79-87, que «relata» imágenes sucesivas de un lugar sentido como primordial y al que regresará inexorablemente el "yo», cumplidas otras etapas de su ser-estar:

\section{Y para siempre}

quiero tocar con mis gastadas manos

la tierra que sostiene mi memoria.

Escribir con un dedo sobre el polvo:

«Es Enrique Molina, una cansada rama del olvido» (p. 80).

La aparición del nombre propio es tanto más espectacular cuanto que designa la identidad como «fuera de sí»: proyectada en la tierra (página) que la fija, la inscribe. Nombrarse es inscribirse como el otro en lo otro, sacralizando esa autonominación. ( $\mathrm{Y}$ este texto sin duda remite al pasaje evangélico: a solas consigo mismo, Jesús, «inclinado hacia el suelo, escribía en tierra con el dedo», y una vez pronunciada la sentencia ante los acusadores de la mujer adúltera, «inclinándose de nuevo en el suelo, siguió escribiendo en la tierra» [San Juan, 8,6-8]. El verso del poema de Molina viola el tabú del nombre propio divino y lo dice.)

El recurso de la autonominación indirecta parece acatar ambiguamente las reglas establecidas por Elizabeth W. Bruss para caracterizar 
el acto autobiográfico: existencia del individuo revelado en el texto como idéntica a la de su autor y abierta a la versificación; la creencia, por parte del autor, en la verdad de lo que transmite (sea o no verdadero); la «escena de la escritura» como ámbito de realización personal ${ }^{4}$. Harto oficioso, sin duda, sería someter a la prueba de verdad los «acontecimientos» registrados por la poesía de Molina, donde la «escena de la escritura» es siempre historia de un «yo». Sutiles reclamos, sin embargo, instan a hacerlo, no sólo desde los poemas mismos, sino también desde otros textos. Así como la autonominación se proyecta en el topónimo, la experiencia amatoria transmitida en los poemas como un acto de subversión ante los códigos de la moral represora también se proyecta y busca anclaje en un suceso histórico, corroborable: los amores de Camila O'Gorman con un sacerdote y su fusilamiento por orden de Rosas en 1848. El relato Una sombra donde sueña Camila O'Gorman "corrobora» la pasión que los poemas monumentalizan: el uno y los otros «hacen historia». En las palabras liminares del relato, Molina - no sin candor cuasi técnico - enfatiza su necesidad de que la poesía sea acceso a la «verdad»:

Un hecho, un personaje histórico, tiene una faz externa, concreta, posible de ser sometida a un juicio de valor. $\mathrm{Y}$ además, una carga sentimental, surgida de un consenso general, una especie de energía que fascina o rechaza y opera como un elemento de imágenes mentales [...] en una total libertad [...]. Del mismo modo que es posible un análisis sociológico, económico, etc., de la historia, imagino también un análisis poético dirigido a captar esa última resonancia de la misma, en el tiempo puro de la conciencia. Para evocar la orgullosa pasión de Camila he tratado de instalarme en esa zona donde se funden en una verdad única el mundo exterior y el interior ${ }^{5}$.

${ }^{4}$ «L'autobiographie considerée comme acte littéraire» (Poétique, 17, 1974, p. 23). Para el perfeccionamiento de esas reglas por su propia autora, cf. Ana María Barrenechea, «Los actos de lenguaje en la teoría y en la crítica literaria» (Lexis, V, 2, 1982, pp. 40-41). Barrenechea también señala la paradoja constitutiva del género autobiográfico, «su complejidad y riqueza» nacidas de la tensión entre la busca de una unidad central del yo que narra su propia historia y la duplicidad del rol acción-escritura, sujeto a la presión de muchas otras fuerzas. En sus trabajos actuales sobre el engendramiento textual de Rayuela, de Cortázar, Barrenechea ilumina las relaciones entre autor y texto, documentadas por el Cuaderno de bitácora llevado por el autor durante el proceso de la escritura. (Cf. «La génesis del texto. Rayuela y su Cuaderno de bitácora» (INTI, IV-V, pp. 959-1980), y otros textos que la autora reunirá en un volumen que publicará en 1983 la Editorial Sudamericana de Buenos Aires.

${ }^{5}$ Cito por la edición de Losada (Buenos Aires, 1973), pp. 77-78. 
La poesía ofrece, pues, el instrumento para satisfacer una avidez ontológica; el relato en prosa reitera actitudes y decisiones del texto lírico: circularidad —en el primer capítulo, el nacimiento de Camila O'Gorman, su primer beso, su muerte se superponen: nace para morir, para que su «sexo torturado» establezca «las más profundas conexiones con las entrañas del universo"-; ruptura constante del discurso histórico y su linealidad con aperturas hacia complejas redes de nuevas interrelaciones temáticas y verbales. Todo ello impulsado por la avidez ontológica declarada desde el texto mismo, que hasta incluye algún tecnicismo aun en medio de la exaltación poética: Camila, maestra en el pueblo de Goya, da a sus alumnos una lección sobre las correspondencias universales y les enseña a redenominar el mundo, toda una literatura de fundación:

¿Qué es un lago?, preguntaban. Una planta, un hueso del cuerpo humano, un animal acuático, respondían según su intuición. Camila les enseñaba entonces el significado por asociación directa, tomaba entre sus manos uno de sus pechos y avanzaba hacia los alumnos [...] veían a través de él una blanca llanura de leche, las nubes y la luna, aprendían que esa forma cálida, redondeada, terminada en un vértice rojo, se llamaba lago. Ya nunca lo olvidarían. Los niñitos deliraban, eran acometidos por fiebres que les provocaban visiones. Ese estado ideal solía durar semanas. Señalaban una gallina, decían surubí; una botella, decían sombrero. Camila sonreía orgullosa, sus alumnos ordenaban el caos. Salían al primer día de la creación, creaban nuevos códigos semánticos, establecían relaciones mágicas, fundaban la realidad» (pp. 202-203).

Verdad, realidad. Se reiteran una y otra vez ambos términos, referidos a una zona primordial, una «escena original» del mundo, la experiencia erótica, el lenguaje, la escritura. (En Camila O'Gorman, la vuelta al origen se da inclusive mediante la interrupción del tiempo histórico. El narrador se identifica con las obsesiones de un personaje que escribe, como testigo inmediato, su propio relato de lo sucedido en 1848 . Y este testigo, a su vez, trasciende el momento histórico, vuelve a la siesta de la "escena original» ("hace diez mil años el sueño de sus trenzas me hacía llorar a gritos, toda una siesta corría tras ella»), ve junto al personaje real Gregorio Araujo, a la actual y también real Lila Mora y Araujo («una remota parienta suya que no conocerá nunca, nacida muchas generaciones después», pp. 207-208).

A esa zona primordial señalada con los rótulos «verdad» y «realidad» también se remontan algunos lectores de Molina. «Podría afirmarse -dice Octavio Paz a propósito de Amantes antipodas-, si la palabra 
no estuviese deshonrada, que es un libro realista. Nada más lejos, por supuesto, que la descripción de la realidad: la poesía de Molina, como un cuchillo, no describe, se hunde en la realidad [...] hay una segunda manera (menos fantástica, no menos imaginativa) [...] donde la pasión se alía a la imaginación: poesía y verdad» ${ }^{6}$. Si no al prurito de verificar las reglas del pacto autobiográfico, estas lecturas se entregan a la fruición de recomponer el discurso de Molina para trazar una suerte de biografía: historia de un «yo» trascendente que sobrevuela el texto y a la vez surge de él. "[...] en Molina -dice Guillermo Sucre- es la experiencia espacial y errante lo que hace de él un verdadero paria $[\ldots]$. Enrique Molina es el poeta de la intemperie [...] y la pasión por conquistarla, conquistándose a sí mismo [...]. Es el poeta que se encara con una vida errante, salvaje y libre; esa vida traduce o no una experiencia personal, pero lo importante es que va creando una experiencia mítica del mundo [...] aunque esa experiencia no se queda nunca en el realismo descriptivo [...] en ella se desarrolla algo infinitamente más complejo y vital: buscar en lo real una dimensión absoluta» ${ }^{7}$. El desdén hacia el cotejo con referentes presuntamente reales se transmuta en la fascinación de otro tipo de referente: la «verdad», la «realidad» últimas que bordean el riesgo de la hipóstasis totalizadora, causa sobredeterminadora del texto. Esta efusión hermenéutica podría reiterar, aunque en sentido opuesto, ciertos excesos de los análisis formalistas: si estos últimos - saludablemente- prohíben un acceso directo a lo real para explicar el modo de significar del poema, y si los primeros parten del texto para describir un modo de ser del mundo previo a toda verbalización, unos y otros no describen la compleja red de mediaciones que vinculan texto y realidad: las transformaciones del texto que representan transformaciones de la realidad ${ }^{8}$. La presencia misma de esas

${ }^{6}$ Citado en Enciclopedia de la literatura argentina (Buenos Aires: Editorial Sudamericana, 1970), p. 456.

7 "La belleza dionisíaca del mundo», en La máscara y la transparencia (Caracas: Monte Avila Editores), pp. 413-421.

${ }^{8}$ Cf. Michel Riffaterre: el análisis que invierte la tendencia de ir desde la cosa representada hacia la representación y hace del texto un punto de partida, «demuestra que el lector no necesita remitirse a su experiencia de lo real (que puede ser inadecuada), porque para comprender y para ver le basta remitirse al código lingüístico (del que por definición tiene experiencia adecuada, sin lo cual no sería lector)». "Le poème comme représentation: une lecture de Hugo», en La production du texte (Paris: Éditions du Seuil, 1979), p. 179. Al código linguístico, sin duda, pero también a los muchos subcódigos metatextuales (tradiciones, normas, reglas) respecto de los cuales el lector tiene mayor o menor competencia. Cf. Jonathan Culler, "The Semiotics of Poetry: two Approaches», en R. T. De George, Semiotic Themes (Lawrence: University of Kansas Publications, 1981). 
mediaciones recomienda no emplear en sentido no metafórico, ni menos aún ornamental, un término como «acontecimiento» respecto de la poesía de Molina. «Acontecimiento» sólo puede admitirse en el sentido que da a la palabra Jurij Lotman: "El acontecimiento en el texto es el desplazamiento de la frontera a través del campo semántico» ${ }^{9}$. El lenguaje de las relaciones espaciales es para Lotman uno de los medios para dar cuenta de la realidad en la semiótica literaria: los modelos históricos del espacio que aparecen en las lenguas naturales (y se desarrollan en los modelos secundarios propuestos por la obra artística) son la base que organiza la construcción de una imagen del mundo. Un modelo ideológico característico de un determinado tipo de cultura y construido como enfrentamiento de espacios mutuamente excluyentes - sin contenido necesariamente espacial, puesto que adquieren los nuevos contenidos de «bueno/malo», «válido/no válido», etc.-, en cada uno de los cuales rigen normas: la convicción de que cada espacio por sí solo impone una imagen única, universal, de la realidad; la impenetrabilidad de las fronteras, cuyo traspaso se considera acto subversivo. Acontecimiento es precisamente traspaso, transgresión, violación del deslinde: «lo que se ha producido habiendo podido no producirse» (Lotman, p. 330). El tema (constituido por una trama de acontecimientos jerárquicamente dispuestos según el movimiento del héroe que traspasa) «es un "elemento revolucionario' con relación a la 'imagen del mundo'» (pp. 332-333) ${ }^{10}$. La obra artística espectaculariza la delimitación de los campos semánticos, latente en la praxis cotidiana, y su especificidad (reiterada, en otra perspectiva, por la metáfora) es una polifonía espacial manifiesta.

«Mientras corren los grandes días», el primer poema de Enrique Molina en su Obra poética, programa esa polifonía semántica de un mundo posible en el cual las fronteras entre espacios se dramatizan como impenetrables y a la vez son traspasadas. Texto con tema, relato de un héroè, que en este sentido puede calificarse como «poeta de la intemperie». Acontecimientos precisos que no sólo se presentan como el traspaso de lo «interior» (lo «doméstico», lo «protegido», lo «invariable») a lo «ex-

${ }^{9}$ Iouri Lotman, La structure du texte artistique (Paris: Gallimard, 1973), p. 326.

${ }^{10}$ Lo cual no sólo concierne a los textos artísticos. «De lo que acabamos de decir acerca del acontecimiento como elemento revolucionario, opuesto a la clasificación recibida, se deriva la ley de desaparición de las noticias de policía en los diarios de épocas reaccionarias» (p. 327). Ni Lotman ni los lectores de otras latitudes necesitamos remontarnos al «siniestro septenio» del fin del reinado de Nicolás de Rusia para ejemplificarlo. Los crímenes de las llamadas «guerras sucias» se callan o se proclaman como «no acontecimientos», mero y formal acatamiento de la norma que impone la supresión del que ha violado una frontera proclamando la validez de otras normas. 
terior» (lo «remoto», lo «amenazado», lo «imprevisible»), sino también como un efecto de esa dialéctica sobre el sujeto que enuncia y protagoniza el traspaso en la instancia del discurso. La transgresión no deja intactos ni al "yo» de la enunciación ni al del enunciado. Uno y otro se presentan como la división misma que los constituye. "Yo" contemplado por otro, testigo que registra a ese otro («todo habla al indefenso y absorto testigo», $P T$, p. 10 ; «siempre irá por tus páramos el pequeño testigo», $P T$, p. 87 ) y hasta la propia identidad física como otro cuerpo («pasa la yema de sus dedos por sus cejas, comprueba de nuevo / sus labios y mira una vez más sus desiertas rodillas», p. 10). $O$ bien se vuelve insatisfecho contra sí mismo como contra alguien que ya lo ha enunciado en el poema y en ese acto se declara otro, «tercera persona» -en los términos de Émile Benveniste- que «ya sabe todo, ya nombró como un rito los objetos / que rodearon su infancia / irremediable y lúcido como el amanecer»; ese «tercero» habla, pero fuera de la instancia en que se dice el poema: sus palabras se citan, llegan desde otra fuente de discurso: "'Mi verdadera alcoba se abre allá lejos' - piensa» $(P T$, p. 58). Un «yo» que, así constituido por la división misma, procura afirmarse a través de la busca obsesiva del otro como diferencia radical: diferencia de sexo. El otro femenino no es todavía en el primer poema de Molina el «tú» de la alocución, sino, una vez más, el «tercero ausente» de ella: alusión a otro cargado de referencia objetiva, situado más allá de las márgenes del discurso, "realidad» que se exhibe como derribo de fronteras, como posibilidad de transgresión al otro espacio:

y los vestidos caen a los pies de la mujer desnudándose (p. 10).

«Mientras corren los grandes días» programa la creación de un mundo posible ${ }^{11}$ que se construye vaciando el mundo actual y colmando el vacío abierto mediante la iridiscencia de espacios distantes. Mundo posible pleno a partir de un vaciamiento inicial. Insistencia de las imágenes, que establecen nuevas conexiones entre los predicados «vaciar» y «colmar» (placer de la dirección del acto de habla que siente al mundo

${ }_{11}$ Para una definición de mundo posible, cf. Umberto Eco, Lector in fabula (Milano: Bompiani, 1979). "Definimos como mundo posible un estado de cosas expresado por un conjunto de proposiciones donde para cada proposición o $p$ $0 \sim$ p.» Las proposiciones que conforman el mundo posible tienen como punto de referencia las que crean la imagen del mundo actual. Tanto la «realidad» como los mundos posibles textuales son construcciones culturales en relación mutua. El mundo posible dependerá de las actitudes proposicionales de alguien que lo afirma, lo cree, lo sueña, lo desea, lo prevé, etc. (p. 128). 
ajustándose a las palabras que lo nombran ${ }^{12}$ ). Mundo posible enmarcado, tanto más convincente al surgir enclavándose en un mundo actual hendido, vaciado. El título del poema y el verso final, que lo reitera, «mientras corren los grandes días sobre la tierra inmutable» (apenas metafóricos, con imágenes ya naturalizadas), son dos predicados, «estados de descripción ${ }^{13}$ de un mundo cuya «verdad» el lector siente corroborada por diferentes discursos (filosófico, científico, literario) que ha incorporado como experiencia vivida desde perspectivas diferentes, inclusive la de la divulgación y la literatura genérica. Ese «estado actual» es invadido por nuevos estados de descripción que se suceden en el discurso del poema: imágenes que se muestran como actos constatativos de la desaparición, la corrosión, el vaciamiento: «Arde en las cosas un terror antiguo». Corroer es colmar de vacío: «un ácido orgulloso que llena las piedras de grandes agujeros». La imagen trabaja en dos niveles: reafirma la experiencia de la permanencia a través de la mutabilidad, anuncia el trayecto del poema: vaciar, colmar. Relleno, entredós, remplissage (= «reparación de encajes desgarrados»). La «tierra inmutable» es el escenario abierto para la transmutación ( $[\ldots]$ y torna crueles las húmedas manzanas, los árboles que el sol consagró [...] los ropajes y los vanos objetos [...] las frutas de yeso y la íntima lámpara donde el atardecer se condensa») y el aparecer de las fronteras entre lo interior y lo externo: «en tanto junto a la tibia habitación, el desolado viento plañe bajo las hojas de la hiedra». Un afuera que en los textos posteriores organizará el tema: el lugar remoto, la toponimia de lo exótico, siempre referidos a la tierra de base: el lugar natal, los sitios de la infancia. La frontera misma entre ambos espacios se tematizará como el lugar transitorio, tierra de nadie: el cuarto del hotel ${ }^{14}$, el camarote, el tren. El lugar mismo asociado a la inmovilidad, el sitio donde se yace, el lecho, se vuelve punto de despegue y traspaso: «Desaparecen sus fronteras / Hay espejismos en las sábanas / Acecha en lo oscuro y jadea: ¡Una gaviota por almohada!» ( $F L$, p. 198). Los lugares transitorios, la frontera traspasada, son el sujeto nómada. Desplazamiento metonímico (como el de la autonominación: del nombre propio al topónimo) que el

${ }^{12}$ Cf. John F. Searle, "A Classification of illocutionary acts» (Language in Society, 5, 1976, pp. 2-3).

${ }^{13}$ Cf. J. Lyons, Semantics (London: Cambridge University Press, 1967), p. 161.

${ }^{14}$ Lo señala la crítica. G. Sucre: «El hotel, en esta poesía, es sólo el signo del carácter libre y liberador del deseo: su máscara y su identidad», op. cit., p. 148. A. Coyné, con imagen de dudosa eficacia: «La palabra hotel es para Molina en todos los idiomas la más bella», prólogo a Amantes antípodas y otros poemas (Barcelona: Ocnos, 1974), p. 9. 
texto exhibe: el lugar de paso adquiere los atributos del que deambula, el extra-vagante: "A diario me instalo en extravagantes lugares / Con grandes deseos de vivir / Comedores anómalos incluidos en los repertorios de la locura» (FL, p. 239).

La dispersión aparente de las imágenes desarrolla la estrategia abarcadora. Abarcadora de nada: de vacío colmado, de fronteras derribadas, de transgresiones y traspasos. Exaltación del propio designio de no lograr, no encontrar. Glorificación de un mundo posible como escenario abierto para la postergación, la salida y el reingreso permanentes. Todo encuentro (unión amorosa, afincamiento) se poetizará como conmemoración o como pura inminencia: lo que se ha tenido, lo que se tendrá. Desde el primer poema, el lirismo se desliza hacia el himno celebratorio (formalmente, al modo de Perse y de Segalen, observa Guillermo Sucre ${ }^{15}$, y sin duda, afín al Neruda anterior al Canto General): «iOh Tiempo! $¡ \mathrm{Oh}$, enredadera pálida! ¡Oh, sagrada fatiga de vivir...!» (p. 10).

Fervor del no encuentro, torturada fascinación de la busca como proceso en la formación de la unidad central del "yo» cuya identidad es el proceso mismo. El himno solemniza esa praxis significante: zozobra ante la posibilidad del encuentro, persecución pero también rechazo de un arraigo que pulverizaría al «yo». Oscilación asumida con ahínco, aunque sin la exacerbación crítica que Octavio Paz ha señalado como rasgo característico de la modernidad ${ }^{16}$. No hay en Molina opciones (metafísicas, religiosas) que se hagan a expensas de otras. Sí la vehemencia revolucionaria del embate contra los códigos (metafísicos, religiosos) esgrimidos por la moral de la prohibición. Pero sobre todo revolucionaria como revuelta permanente: giro sobre sí, circularidad. "No hay sentimiento que arroje en la exuberancia con más fuerza que el de la nada. Pero la exuberancia de ninguna manera es la aniquilación: es la superación de la actitud aterrada, es la transgresión» (Georges Bataille) ${ }^{17}$.

Se transgreden fronteras para superar el terror de un sagrado. $\mathrm{Y}$ lo sagrado que el poema glorifica es el traspaso mismo, la oscilación, partida y retorno simultáneos. Celebración, sacralización de la vacilación, de la duda como rasgo constitutivo del «yo».

${ }^{15}$ Op. cit., p. 421.

${ }^{16}$ Los hijos del limo (Barcelona: Editorial Seix Barral, 1974).

${ }^{17}$ El erotismo (Buenos Aires: Editorial Sur, 1957), p. 67. 
«EN LA POESÍA, EL LENGUAJE DE LA DUDA DEBE SER INDUDABLE» (MIJAIL BAJTIN)

Altivez y aun arrogancia de la duda. Otra faz con que se muestra en la poesía de Enrique Molina la ilusión de un pacto autobiográfico producida a partir de la elección de rumbos divergentes: ficcionalización de actos de habla al modo de los reales, y a la vez inscripción de esos actos en una amalgama de metatextos literarios. Por un lado, la poesía hímnica de la celebración; por el otro, la modalidad surrealista, con su identificación de vida y poesía, acción verbal no como poiesis, sino como praxis que no quiere agotarse en pura mimesis de acciones reales, y se proclama como acción inmediata y concreta, cargada de contenidos éticos que embisten precisamente contra los códigos de la moral oficial: apertura a la liberación, desenmascaramiento de lo falso ${ }^{18}$. Todo ello no acatado por Molina como la ortodoxia de una receta. Opciones contradictorias; la norma se elige, una vez más, como posibilidad de transgresión: a) el himno quiere resonar como una voz comunitaria, unánime: discurso fuertemente aislado, sin contrario dialéctico; $b$ ) el texto surrealista quiere actuar como un revulsivo químico, irritando los modos de recepción del lector y provocando en él nuevos discursos que invadan el que le es destinado por el texto: «El lirismo es el desarrollo de una protesta» ${ }^{19}$; c) la ficcionalización de un hablar real mimetiza una situación de intercambio discursivo. Pero en la poesía de Molina (como en toda poesía) el lenguaje es perentorio, dogmático, impenetrable por otras voces. «El estilo poético está convencionalmente alienado de toda acción recíproca con el discurso de otro, de toda 'mirada' hacia el discurso ajeno [...]. Sin embargo, el plurilin-

${ }^{18}$ Un cuarto de siglo después del estallido surrealista, Philippe Soupault escribía: «El surrealismo no es, después de todo, una escuela literaria o una religión; es la expresión de una actitud, un estado de alma y sobre todo una señal de liberación. Las fórmulas, definiciones, máscaras que han intentado no han logrado disminuir su fuerza» («Traces which last», en Surrealism, Yale French Studies, 31, 1964, p. 22). $Y$ en 1982, Enrique Molina: «Pero -insisto- es un error tomar por surrealistas a poetas que, a pesar de emplear en ciertos momentos un lenguaje que podríamos llamar parasurrealista, no lo son en absoluto por su espíritu.» De ahí que sea imprescindible subrayar que ese movimiento no es una escuela literaria a la manera del modernismo o el ultraísmo, centrados en formas expresivas, sino -más decididamente- un humanismo poético.» Cf. Danubio Torres Fierro, «Un poeta en la intemperie», entrevista a Enrique Molina (Revista de la Universidad de México, 9, enero de 1982, p. 32).

${ }^{19}$ En Notes sur la poésie (Paris: Gallimard, 1936; reproducido en Littérature, 1924). 
güismo (otros lenguajes socio-ideológicos) puede integrarse en los géneros estrictamente poéticos, sobre todo en el habla de los personajes. Pero ese plurilingüismo está objetivado, mostrado, en suma, como una cosa. No está en el mismo plano que el lenguaje real de la obra: es el gesto representado del personaje» (Mijail Bajtin) ${ }^{20}$. En los textos de Molina, el otro (parte esencial de la constitución del «yo» como habitante del espacio remoto cuya frontera transgrede: hipóstasis necesaria para confirmar la actividad permanente de un proceso constructivo) ni siquiera aparece representado (salvo ocasionalmente) por un discurso propio: sólo hay expectativa de ese discurso-réplica que, por las condiciones mismas de realización del poema (soliloquio constante), no podría manifestarse. La pregunta y la orden dirigida al otro no es estímulo para que hable, sino para obligarlo a un actuar fantasmático, desde más allá del diálogo unilateral ficcionalizado. El otro debe estar presente como inminencia, debe obligar al «yo» a la evocación («tornemos a los viejos y rientes fantasmas / en donde todavía hemos amado... ¿Pueden reconocernos ellos, que antes amaron / con nuestros propios gestos?», $C D$, p. 15), hacerle imaginar que en el momento mismo de la unión ambos ya están proyectados hacia el tiempo en que se los recordará como desaparecidos ( $\mathrm{Y}$ ahora, amor mío, / a ciegas por el largo camino de tu cuerpo / tanta vida desdobla sus vertientes ambiguas, / quizá ternura, quizá terror: / ya todo está listo para el funeral del recuerdo», US, p. 56) o como lo inmemorial ( Hace mil años abandonamos el último beso en una noche / devorada por la montañas», $C E$, p. 100). A diferencia del lenguaje hablado en situaciones corrientes, fuertemente proyectado hacia el discurso-réplica anticipado, constituido por la atmósfera de lo «ya dicho» en una multitud de contextos privados de que participan los hablantes, el lenguaje de la poesía, y en particular la de Molina, no anticipa: crea, inventa la gama de respuestas posibles, que nunca llegan, salvo en el estallido hímnico del propio poema. Se ficcionaliza la expectativa - y aun el temor- de una respuesta; el receptor imaginado como alguien más allá de la situación de discurso parece reclamar como entidad real sus propios derechos de interlocutor en potencia. Pero nunca presente, nunca ficcionalizado como interlocutor. Su conducta ha de ser la de la ausencia, la reclusión en otro espacio que permita el avance, el traspaso del «yo». La presencia o «retorno» del tercero ausente al espacio de la enunciación prohibiría al «yo» el proceso mismo de su propia construcción, lo amenazaría de muerte. Imaginando ese retor-

${ }^{20}$ Mikail Bakhtine, Esthétique et théorie du roman (Paris: Gallimard, 1978), pp. 107-109. (Traducción mía.) 
no como una vuelta, no al origen, sino al estatismo, el «yo» se dirige a sí mismo como al otro, al «tú» del diálogo imposible, y lo intima:

Pero si regresas sólo encontrarás

La negra sangre del reloj coagulada sobre los maderos

O el cordaje dormido de una hoguera de antaño solamente

pulsada por una mano de exilio

En esa hora enmallada de sombra como un verdugo

En la morada donde nada existe

Como no sean esas aguas sin rumor que algunos beben para morir

y los menos audaces denominan recuerdo ( $C E, \mathrm{p} .109)$.

El otro femenino es así lo perpetuamente remoto, «la mujer lejanísima que ahora una vez más respira como una isla de pasión entre mis brazos» ( $A A$, p. 160). De la metáfora, al símbolo: como en una traducción verbal de un posible cuadro de Magritte, la mujer es el ropaje que oculta al fantasma del deseo desnudo: "y con vagones tapizados de musgo con un asiento donde viaja un vestido vacío de mujer de lana verde a cuadros» (CE, p. 123).

La obsesión erótica no es desenfreno sexual: es imposición y derribo del límite, proyección del «yo» en un «tú» cuya existencia se declara vicaria: representante de la necesidad de ser dejando de ser y convirtiendo esa necesidad en el trayecto mismo de una descentralización que vuelve empecinada al punto de arranque. La transgresión máxima no es la violación de los tabúes sexuales del mundo burgués (como en Camila O'Gorman, donde, por otra parte, tal violación es a su vez vicaria de otro tipo de transgresión). Es el rechazo terminante de canonizaciones tales como la fusión amorosa en un «tú» trascendental, o la entrega al placer físico como contraparte imprescindible del placer espiritual. La transgresión tampoco es aquí la canonización de la duda como bien en sí, lujo, excedente superfluo de los reclamos de acción exigidos por el devenir histórico. La duda es rotación centrípeta y centrífuga a la vez, espiral en continuo movimiento, salida y entrada en el "yo» que se construye como ruptura y unión, discontinuidad continua, afirmándose y negándose en el otro. Otro cuyo discurso está ausente, pero que desde sus imposibles respuestas organiza todo el discurso poético. Y lo hace sin cesar en torno de dos ejes: el mandato-pregunta (como en los llamados «actos de habla derivados», con toda una constelación de estructuras profundas tan diversas como la orden, la súplica, el consejo, la autorización), la exclamación, el himno a lo que de ese modo ha sido creado: el mundo posible engendrado por la oscilación y la duda. Ven- 
cido el terror (como llama Paulhan el rechazo de la retórica ${ }^{21}$ ), asumida la duda en el dogmatismo del lenguaje poético, preguntas y órdenes retóricas crean una obligación de respuesta no ya en el fantasmático «tú» ausente-presente en el poema, sino en el lector, en quien se quiere suscitar la respuesta afirmativa frente al mundo que se le propone. La exclamación, el himno son respuestas anticipadas.

Poema arquetípico, en este sentido, es «Los buenos consejos» (US, p. 69), donde la serie orden-pregunta-exclamación afianzan la coherencia del microuniverso integrado por espacios enfrentados:

a) «Sé dócil, una ciega presencia, sin perder el arrullo de tu íntima ferocidad $[\ldots] . »$

b) «Acéptalo / Oirás voces, frases desconocidas, llorarás tan cerca, $\tan$ lejos $[\ldots .$. .»

c) «¿Ves el fantasma de la monja desnuda, a lo largo de un claustro, a la luz de la luna?»

d) «Oh, pero tú eres de carne, de carne imprevisible y voluptuosa.»

El mandato, la súplica, la pregunta exhortativa no siempre se dirigen al otro creado por la exhortación misma. En ocasiones (sobre todo en los primeros textos de Molina), es a sí mismo a quien el «yo» invoca («Vuélvete, y en la sombra, / tal como torna el pródigo perdido, / regresa hacia ese légamo de fucos / donde vela el recuerdo de tu gente», $P T$, p. 49). Y en muchos de esos casos lo hace ambiguamente, intimando a un receptor que abarca a un ser múltiple: «yo» y «el otro». En el poema «Ahora llueve muy lejos de esa noche» (CE, p. 111), donde se conmemora a los amantes en la unión amorosa, el imperativo parece destinado al uno y al otro: «Deja que el lobo aúlle en la intemperie / Déjalo que se abrigue al gran sol de la duda.» Pero en esencia, tanto el uno como el otro - el «yo» proyectado, la amada remota- son idénticos: esa «tercera persona» ausente que, por obra de la función mágica o incantatoria descrita por Roman Jakobson ${ }^{22}$, se vuelve destinataria del mensaje conativo.

La exhortación, la pregunta, la exclamación colman un vacío: el del nombre propio, el del tercero ausente. Pronunciado, ese nombre lo haría

${ }^{21}$ Cf. Severo Sarduy, Escrito sobre un cuerpo (Buenos Aires: Editorial Sudamericana, 1961), p. 57.

${ }^{22}$ Ensayos de lingüistica general (Barcelona: Editorial Seix Barral, 1975), p. 356. Cf. en la excelente lectura de Ana María Barrenechea la presencia subyacente de la fórmula linguística ritual en un poema anónimo de la Edad Media recogido por Dámaso Alonso en versión quizá renacentista (op. cit., pp. 44-45). 
comparecer como presencia inmediata. Pero el nombre se calla. El otro femenino, el propio "yo» invocados son siempre cuerpos arrebatados por el deseo de la unión carnal, pero nunca «actuales» ni inmediatos ( Quizá sea de verdad / esa mujer que late al final de mis dedos», $C D$, p. 34; «¿Estuvo allí mi cuerpo un día / Prisionero de ardientes redes / junto a otros cuerpos tenebrosos / con la hostia de los hoteles?», $F L$, p. 217). Y adquieren una dimensión cósmica. Espacio total: no sobrenatural, pero sí surreal ( $L$ La vraie vie est ailleurs», dijo el surrealismo), que incita al himno celebratorio: «iAlma en un territorio de delicias!» (PT, p. 71).

El poema se precipita hacia la exaltación mítica, quiere ser texto mítico. Y así quieren sentirlo no sólo el «yo» creado por el texto y que en su interior se contempla a sí mismo, sino también, fuera de él, un lector que es el propio autor, el hombre autor del poema: Enrique Molina. Si se le pregunta: «¿Cuál sería el sentido último de su poesía?», Molina responde: «... expresar la naturaleza 'tantálica' de la existencia. En el mito - como se sabe-, Tántalo está condenado al deseo perpetuo.» Si Molina reflexiona sobre la edición de su Obra poética -en una página que significativamente denomina «La divinidad está en las cosas»-, se responde: «... comprendí que en los ocho libros publicados había un solo poema, o un poema siempre repetido con distintos destellos. En la diversidad infinita del mundo, ciertos mitos se nos imponen" ${ }^{23}$.

¿Qué mitos? No tanto uno cuanto la conciencia mitológica del mundo, que inspira a Molina interminable nostalgia. Nostalgia de la nominación mítica, del nombre propio que conjura la aparición de lo nombrado, suprime distancias y vuelve idénticos el nombre y el ser nombrado. En la destrucción misma de la conciencia mítica, Jurij Lotman ha señalado la aparición de las condiciones necesarias para el desarrollo de la poesía, el crecimiento imprevisto de la «flexibilidad de la lengua», la proliferación de la sinonimia, la metáfora, el símbolo. «La identificación mitológica nunca es una sinonimia. La sinonimia presupone, para un mismo objeto, la presencia de varios nombres intercambiables. La identidad mitológica tiene un carácter fundamentalmente extratextual, dado que se funda en la inseparabilidad del nombre y de la cosa» ${ }^{24}$. La nostalgia del mito genera la construcción metafórica, el pensamiento por imágenes, que a su vez procura encontrar el regreso al mito «en la realiza-

${ }^{23}$ C. Danubio Torres Fierro, op. cit., pp. 32, 33.

${ }^{24}$ Jurij M. Lotman y Boris A. Uspenskij, «Mito, nombre, cultura», en Semiótica de la cultura (Madrid: Ediciones Cátedra, p. 132). 
ción de la metáfora, en su interpretación literal (interpretación que anula la misma metaforicidad del texto)» ${ }^{25}$. Es el intento surrealista.

Ultima faz del ilusorio pacto autobiográfico en Molina: esta vez consigo mismo. Buscando en la imagen poética la visión de la propia identidad, haciendo de ella reflejo especular ( Palabras de espejo ante la boca para saber si he muerto», $B F$, p. 226), el poeta transgrede el tabú del nombre propio que, pronunciado, identificaría ser y palabra, y suprimiría la mediación poética. Surge así la ocasión única en que el nombre propio es inscrito en el texto. Transgresión de la transgresión: la frontera entre el espacio del signo y el de lo nombrado ya no parece traspasada, sino eliminada. Pero aun en esa ocasión única, el nombre propio no se deja encerrar en el espacio cerrado del mito. Se abre, se explica, se traduce en la imagen:

Es Enrique Molina, una cansada rama del olvido.

Pronunciar, olvidar el nombre. Recordar, retornar a la poesía.

${ }^{25}$ Ibid., p. 126. 